\title{
Effect of Bacillus thuringiensis-Induced Carrier Composition and Solvent on Yield of Lantana camara Bioactive Compound
}

\author{
Agung Astuti ${ }^{1 *}$, Dina Wahyu Trisnawati ${ }^{1}$, Anggi Cahyani ${ }^{1}$ \\ ${ }^{1}$ Department Agrotechnology, University of Muhammadiyah Yogyakarta, Indonesia \\ ${ }^{*}$ Corresponding author. Email:agung_astuti@yahoo.com
}

\begin{abstract}
Insecticidal efficacy of Lantana camara is affected by the efficacy of formulation used determined by the concentration of its bioactive compound. The use of Bacillus thuringiensis (Bt) could induce the fermentation of L. camara and the selection of compatible solvent might contribute in production of its bioactive compound. This study was aimed to evaluate the effect of $B$. thuringiensis-induced carrier composition and solvent types on the yield of L. camara bioactive compounds. This study was conducted using completely randomized design consisting of two separately performed assays, namely evaluation of $B t$-induced carrier composition and evaluation of solvent types. Assessment of carrier composition consisted of five treatments, such as (1) $B t$ with POME (palm oil mill effluent), (2) $B t$ with POME: coconut water (1:3), (3) $B t$ with POME: coconut water (1:1), (4) $B t$ with POME: coconut water (3:1) and (5) $B t$ with coconut water. Extraction of $L$. camara bioactive compound was further evaluated through solid extraction with various types of solvent, such as methanol, ethanol and acetone. During the fermentation of L. camara with all Bt-induced carrier compositions, significant $\mathrm{pH}$ drop was recorded after six days without any remarkable temperature change. From the solid extraction, the highest yield of bioactive compounds (15\%) was produced by $L$. camara fermented in $B t$ with POME: coconut water (1:1) and extracted with acetone.
\end{abstract}

Keywords-Bioactive compounds, Lantana camara, Bacillus thuringiensis, carrier, solvent

\section{INTRODUCTION}

Lantana camara is one of weed species commonly found in oil palm plantation. This weed showed promising insecticidal activity against some plant pests, including nettle caterpillar (Setora nitens). This pest had been major pest in oil palm plantation and caused yield loss up to $35 \%$ [1]. However, the insecticidal effect of this weed for field application was determined by the formulation used.

Previous studies reported the synergistic effect of $L$. camara and Bacillus thuringiensis $(\underline{B t})$ when produced using palm oil mill effluent (POME) and coconut water [2]. Generally, the making process of biopesticide is usually carried out by fermentation process, thus resulting in both liquid and solid products. However, this solid product oBtained was commonly low in concentration and reduced the bioactive compound as well as its insecticidal efficacy. Therefore, solid extraction was highly recommended to produce higher amount of bioactive compound, thus resulting better insecticidal effect.

The success of solid extraction depended on the compatibility between the bioactive compound and the solvent type used. Selection of highly compatible solvent might double up the production of bioactive compound.
Suryani et al. [3] reported the production of bioactive compound in matoa leaves could reach $38.68 \%$ when extracted using methanol. In this study, the presence of $B t$ might contribute in stimulating better quality of $L$. camara fermentation. Moreover, solid extraction carried out after the fermentation might potentially increase the bioactive compound released from L. camara thus resulting in higher insecticidal effect. Therefore, this study was aimed to evaluate the $B t$-induced carrier composition and solvent type that could stimulate high yield of $L$. camara bioactive compound.

\section{METHODS}

\subsection{Fermentation of L. camara with Bt-induced Carrier Composition}

L. camara powder was fermented using five different combinations of $B t$ carrier composition, namely (1) $B t$ with POME (palm oil mill effluent), (2) $B t$ with POME : coconut water (1:3), (3) $B t$ with POME : coconut water (1:1), (4) $B t$ with POME : coconut water (3:1) and (5) $B t$ with coconut water. Each combination was supplemented with $10 \%$ (w/v) brown sugar. The fermentation was carried out for 6 days as 
recommended by Alavie [4]. Physical changes of the culture ( $\mathrm{pH}$, temperature, color and aroma) as well as density of $B t$ cell were observed every two days.

\subsection{Solid Extraction of L. camara Bioactive Compound}

Solid phase resulted from L. camara fermentation was further macerated with different solvents, such as methanol, ethanol and acetone for 24 hours. After the maceration, the solution was filtered and subjected to rotary evaporator at $30^{\circ} \mathrm{C}$ to extract the bioactive compound [5]. Yield of bioactive compound oBtained from each solvent was calculated based on the ratio of final weight to initial weight [6].

\section{RESULTS AND DISCUSSION}

The use of different ratio between POME and coconut water $(\mathrm{CW})$ in the $B t$ culture resulted in different physical change on L. camara fermentation. Regarding the temperature change during 6 days fermentation, Figure 1 showed no significant temperature rise in all carrier compositions. However, remarkable $\mathrm{pH}$ drop was recorded in all compositions (Figure 2) indicating the degradation of both POME and/or coconut water by Bt. Other physical change occurred during the fermentation was color and aroma. All carrier compositions were changed into dark brown-colored (Table 1) and emitted stink odor after 6 days fermentation.

This degradation is the key indicator of fermentation as it triggers the conversion of organic compounds into energy [7]. The presence of $B t$ stimulated the hydrolysis enabling the breaking of polysaccharides into simple sugar molecules, thus resulting in energy production. As the fermentation process occurred, physical characteristic of the raw materials would change significantly indicated by the temperature rise, $\mathrm{pH}$ drop, color change and odor emission. Temperature rise played a role in enhancing the enzymatic activity required during the fermentation. However, the rise should be carefully controlled to prevent excess heat triggering the enzyme denaturation and microbial growth inhibition. Therefore, it is important to maintain the temperature in the range of growth requirement of the microbes [8].

Significant $\mathrm{pH}$ decrease was stimulated by the production of organic acid due to the breakdown of sugar molecules [9]. This pH drop affected the growth $B t$ indicated by the cell density (Figure 3) during the fermentation process. Since the decrease reached the highly acidic condition, it then inhibited the growth of $B t$ at the final day of fermentation. $B t$ could grow in the range of $\mathrm{pH} 5.5-8.5$ and reach its optimal growth in the range of neutral $\mathrm{pH}$ 6.5-7.5 [10].

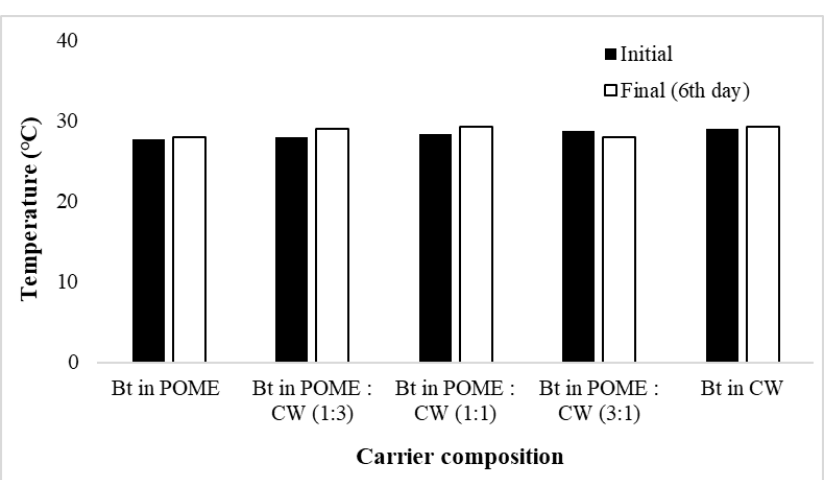

Figure 1. Temperature change resulted in L. camara fermentation under various $B t$-induced carrier composition. POME, palm oil mill effluent; $\mathbf{C W}$, coconut water.

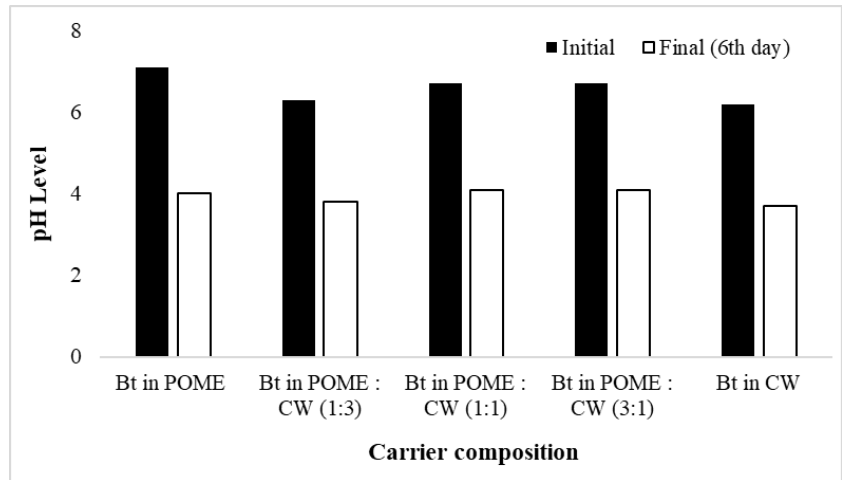

Figure 2. $\mathrm{pH}$ change resulted in $L$. camara fermentation under various $B t$-induced carrier composition. POME, palm oil mill effluent; $\mathbf{C W}$, coconut water.

Color change of the raw material was associated with chlorophyll degradation, thus resulting in browning effect. Alavie [4] showed that browning reaction involving the compounds convertion, particularly the oxidation from quinol to quinone. In addition, odor emitted from the fermentation process become more pungent from day to day and tended to be stink. The characteristic of smell resulted from the fermentation process was mostly associated with sugar conversion. However, proteolytic activity mediated by $B t$ also contributed in resulting this foul aroma due to the hydrolysis of protein and other nitrogen compounds [11]

Table 1. Color change resulted in L. camara fermentation under various $B t$-induced carrier composition. POME, palm oil mill effluent; $\mathbf{C W}$, coconut water.

\begin{tabular}{ccc}
\hline Carrier composition & Initial & Final $^{\text {th }}$ day $)$ \\
\hline \multirow{2}{*}{$B t$ in POME } & $3 / 32.5 \mathrm{Y}($ Dark & $3 / 310$ YR (Dark \\
& Olive Brown) & Brown) \\
\hline$B t$ in POME $:$ CW & $5 / 62.5$ Y (Light & $3 / 310$ YR (Dark \\
$(1: 3)$ & Olive Brown) & Brown) \\
\hline$B t$ in POME $:$ CW & $3 / 32.5$ Y (Dark & $2 / 210$ YR (Very \\
$(1: 1)$ & Olive Brown) & Dark Brown) \\
\hline$B t$ in POME $:$ CW & $3 / 32.5$ Y (Dark & $3 / 310$ YR (Dark \\
$(3: 1)$ & Olive Brown) & Brown) \\
\hline \multirow{2}{*}{$B t$ in CW } & $4 / 42.5$ Y $($ Olive & $2 / 210$ YR (Very \\
& Brown) & Dark Brown)
\end{tabular}




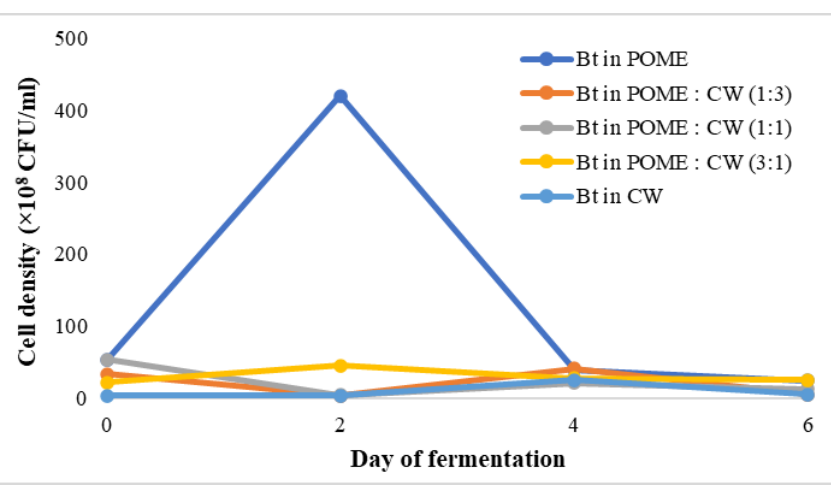

Figure 3. Effect of $L$. camara fermentation towards the dynamics of $B t$ growth. POME, palm oil mill effluent; $\mathbf{C W}$, coconut water.

Regarding the growth of $B t$, the presence of both POME and coconut water successfully maintained the $B t$ growth even in highly acidic condition (Figure 3 ). It was indicated that POME and/or coconut water provided the nutrition required for $B t$ growth, thus enabling stable cell density during the six days of fermentation. This finding was in line with Wahyuono [2] mentioned that addition of coconut water and POME enabled $B t$ to enter its exponential (log) phase since the first day. Moreover, it was assumed that content in $L$. camara also contribute nutritional effect for $B t$ growth. Similar studies reported that addition of $10 \%$ L. camara resulted in the highest $B t$ growth during 6 days of fermentation. Several natural compounds were reported found in L. camara leaves and potentially contributed as the nutrients for $B t$, such as alkaloids, lantanine, flavonoids and also terpenoids [4].

Regarding the extracted bioactive compounds, L. camara extracted with acetone showed higher yield up to $15 \%$, especially the one previously fermented in $B t$ culture supplemented with POME : coconut water (1:3) (Figure 4). According to this result, it was assumed that the bioactive compounds of $L$. camara had the same polarity with acetone, thus resulting in higher yield of oil extracted. Moreover, the initial fermentation mediated by $B t$ in POME : coconut water (1:3) was predicted to release higher amount of $L$. camara bioactive compound.

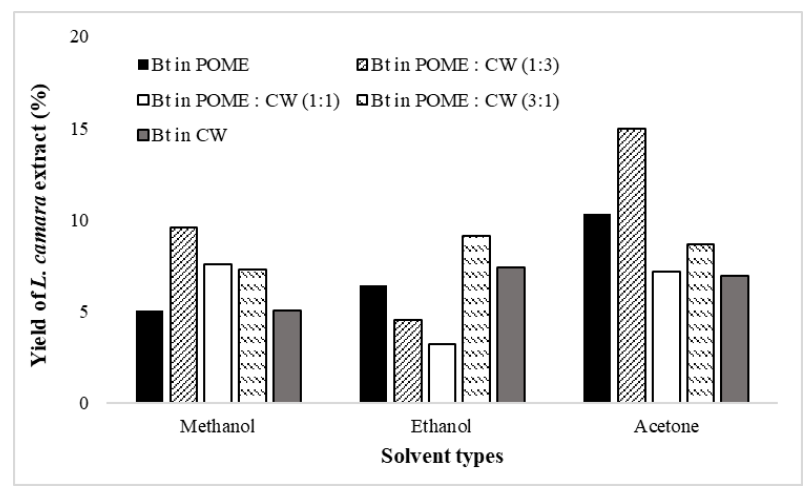

Figure 4. Effect of solvent types on yield of L. camara bioactive compounds.

\section{CONCLUSION}

This study had proven that $B t$-mediated fermentation with addition of POME and coconut water then followed with acetone extraction had successfully enhanced the yield of L. camara bioactive compounds.

\section{REFERENCES}

[1] B. N. Paranngin-angin, "Ulat api (Limacodidae) dan ulat kantong (Psychidae) serta musuh alami pada pertanaman kelapa sawit (Elaeis guineensis Jacq.) PTPN VIII." 2009.

[2] D. Wahyuono, "Kajian Formulasi Bacillus Thuringiensis Dengan Carrier Limbah Cair Pabrik Kelapa Sawit Untuk Pengendalian Ulat Api (Setora nitens)," Planta Tropika: J. Agro Sciences, vol. 3, no. 1, pp. 24-30, 2015, doi: 10.18196/pt.2015.036.24-30.

[3] N. C. Suryani, D. G. M. Permana and A. G. A. Jambe, "Pengaruh Jenis Pelarut Terhadap Kandungan Total Flavonoid Dan Aktivitas Antioksidan Ekstrak Daun Matoa (Pometia pinnata)," J. Ilmu dan Teknologi Pangan., vol. 5, no. 1.

[4] T. Alavie, A. Astuti and D. W. Trisnawati, "Pengaruh Konsentrasi Lantana camara dan Lama Fermentasi dengan Bacillus thuringensis Terhadap Hama Ulat Api Setora nitens Pada Kelapa Sawit," http://repository.umy.ac.id/, 2017.

[5] W. Pakaya, "Analisis Kadar Flavonoid Dari Ekstrak Metanol Daun Bunga Tembelekan," J. Penelitian, 2015.

[6] T. W. Senduk, L. A. Montolalu, V. Dotulong, S. Ratulangi, U. S. Ratulangi and K. U. Bahu, "Rendement of Boiled Water Extract of Mature Leaves of Mangrove (Sonneratia alba),"J. Perikanan dan Kelautan Tropis, vol. 11, no. 1, pp. 9-15, 2020.

[7] Suprihatin, Teknologi Fermentasi. Surabaya: Unesa Press, 2010.

[8] B. Blondine, "Pengembangbiakan Bacillus thuringiensis H-14 Galur Lokal Pada Berbagai Macam pH Media Air Kelapa dan Toksisitasnya Terhadap Jentik Nyamuk Vektor Aedes aegypti dan Anopheles aconitus" Media Penelitian dan Pengembangan Kesehatan, vol. 20, no. 1, 2010.

[9] T. Rahayu and T. Rahayu, "Optimasi Fermentasi Cairan Kopi dengan Inokulan Kultur Kombucha (Kombucha Coffee)," J. Penelitian Sains dan Teknologi, vol. 8, no. 1, pp. 15-29, 2007.

[10] R. U. Bernhard K., Production of Bacillus thuringiensis Insecticides for Experimental and Commercial Uses. Chichester, 1993.

[11] Winarno, Pengantar Teknologi Pangan. Jakarta: PT. Gramedia Pustaka Utama, 1980. 